\title{
THE PRACTICE OF ETHNIC LABELING IN THE CARTULARY OF ST PETER DE GUMAY NEAR SPLIT
}

\author{
Neven Budak
}

\author{
N. Budak \\ University of Zagreb \\ Faculty of Humanities and Social Sciences \\ Department of History \\ Ivana Lučića 3, HR-10000 Zagreb \\ nbudak@ffzg.hr
}

\begin{abstract}
The monastery of St Peter de Gumay was founded sometime around 1080. Its cartulary contains notes written mostly before 1105 and not later than 1241. There are a few notes from the $14^{\text {th }} \mathrm{C}$. Ethnic names were only rarely used by the scribes of the cartulary. Although we could expect a more often use of designations 'Croats', 'Dalmatians', 'Slavs' or 'Latins', in the first part of the cartulary there are only three mentions of Croats and never any of the other three identities. There are also designations of local origin. The most frequent is 'de Tugari', meaning people from the village (district) in the vicinity of the monastery. In a similar way there are described also other people living in nearby villages or districts. A somewhat broader 'circle of identification' comprises inhabitants of different Dalmatian towns.

The lapidary genealogy of the family of Rusin Morsticus poses the question about the relation between Slavs and others (as does the 1176 charter regarding a dispute between the monastery and certain 'Slavs' and 'Latins'). Rusin Morsticus was a Croatian dignitary who's brother was Slauiz rex. In the 1176 charter Rusin's donation was confirmed by his son, Petrus Slauus and by Peter's uncle Slauizo. This means that the designation 'Slav' was used for the members of this lineage through two generations. Why was exactly this family highlighted as being Slavic, in a surrounding in which the majority had Slavic names and obviously spoke Slavonic remains unclear. By the second half of the $11^{\text {th }} \mathrm{c}$. even the citizens of Split were strongly Slavicized. A few decades later the Split historian Thomas the Archdeacon will distinguish clearly between Latins (citizens of Dalmatian towns) and Croats (or Slavs, whom he sometimes identifies with Goths). The last part of the cartulary, containing notes from the $14^{\text {th }}$ century, differs from the previous parts in mentioning more often the Croatian name. The organizing and strengthening of the lesser nobility which gathered into the 'Brotherhood of the twelve Croatian tribes' resulted in an early expression of 'national' identity among all strata of nobility and found its way onto the pages of the cartulary.
\end{abstract}

Key words: ethnic identity, national identity, Croatia, Dalmatia, central Middle Ages

The cartulary of the Benedictine monastery of St. Peter de Gumay near Split is one of the most important sources for the history of the Croatian High Middle Ages. ${ }^{1}$ The monastery was founded by a wealthy citizen of Split, a certain Peter Crni (the Black) de Gumay, sometime around 1080. ${ }^{2}$ The cartulary contains a number of records on the building of the church of St. Peter and the later founda-

\footnotetext{
${ }^{1}$ The best edition of the cartulary is V. NOVAK, P. SKOK (eds.), Supetarski kartular, Zagreb, 1952 (further: Supetarski kartular). There is also an English translation: E. PIVČEVIĆ (ed.), S. J. TESTER (transl.), The Cartulary of the Benedictine Abbey of St Peter of Gumay (Croatia), 1180-1187, Bristol, 1984.

${ }^{2}$ On the dating of the foundation of the monastery: Supetarski kartular, 189-194; N. BUDAK, Prva stoljeća Hrvatske, Zagreb, 1994, pp. 118-119.
} 
tion of the monastery, on lands and slaves purchased by Peter for the maintenance of the monastery and on several disputes and law suites with neighbours. It was used as a source by several historians researching social and political history, but, to my knowledge, never as a source for the investigation of identities, ethnic or local, with the exception of the problem of the existence of a separate Narentanian principality in the second half of the eleventh century. ${ }^{3}$

The cartulary contains notes written by different authors at different times. A thorough paleographic analysis was made by Viktor Novak in the mentioned edition of the cartulary. ${ }^{4} \mathrm{He}$ identified two scribes in the first part of the manuscript, both writing during the early $12^{\text {th }} \mathrm{c}$. and using the Carolingian script, whereas one of them reveals strong Beneventan influences. Novak believes that the incentive for the composition of the text came with a dispute about some lands which had been solved at the synod held in Zadar in $1105 .{ }^{5}$ According to Novak, it was then that Abbot Gregory decided to copy all the charters related to the property of the monastery into one volume. This part comprises all notes composed by Peter and his successors and in the edition of the cartulary marked with numbers 1-96. This is followed by note No 97, written down in 1176 by the Split notary Gualterius, and note No 98, written by the Split subdeacon and notary Sabbatius in 1187.6 Obviously, all other notes following this last one had to be written down some time after 1187. Note No 99 is a list of books kept in the monastic library, written in Beneventan script, followed by No 100, a note on the alleged custom of electing kings in Croatia, again in Carolingian script. This note, together with all the rest (101-106) were written, according to Novak, in the $14^{\text {th }} \mathrm{c} .{ }^{7}$ Novak also believes that at the time when these notes were inserted into the cartulary, the manuscript was already kept in Split, in the chancellery of the archbishop or the chapter, because the monastery of St Peter had been abandoned during the Mongol invasion in 1241. This is a probable thesis, although archaeological research suggests that the church itself was renewed sometime in the $13^{\text {th }}$ or $14^{\text {th }} \mathrm{c}^{8}$

The subject of Early Medieval identities was discussed recently in relation to the question of the origins of Croats. Although this topic has been of utmost importance for Croatian historians since the mid-nineteenth century and has been discussed also by numerous other scholars, it was only since the late 80-ies of the past century that evidence became scrutinized with more awareness about the necessity of a theoretical background for such research. Mostly under the influence of the Vienna school (Herwig Wolfram and Walter Pohl), Croatian scholars started thinking about other possibilities for the appearence of Croats in Dalmatia rather than a large migration of an already formed people (Slavic, Iranian or some other) either in the first half of the seventh, or at the end of the eighth century. ${ }^{9}$ More recently, the idea arose that the Croats formed themselves as a social/ethnic group only during the first half of the ninth century, following the turmoils of the Byzantine-Frankish war for Dalmatia, Istria and Venice. ${ }^{10}$

\footnotetext{
${ }^{3}$ N. KLAIĆ, Problem Slavca i Neretljanske krajine, in: Zgodovinski časopis 14, 1960, pp. 96-136; S. GUNJAČA, Ispravci i dopune starijoj hrvatskoj historiji, vol. III, Zagreb, 1975, pp. 13-70.

${ }^{4}$ Supetarski kartular, pp. 119-141.

${ }^{5}$ Supetarski kartular, p. 129.

${ }^{6}$ Supetarski kartular, pp. 131-132.

${ }^{7}$ Supetarski kartular, p. 136. Novak rejected the opinion of Ferdo Šišić, who dated some of these notes into the $15^{\text {th }}$ or even $16^{\text {th }}$ c. F. ŠIŠIĆ, Enchiridion fontium historiae croaticae, Zagreb, 1914, p. 380.

${ }^{8}$ Supetarski kartular, p. 139.

${ }^{9}$ N. BUDAK (ed.), Etnogeneza Hrvata, Zagreb, 1995; L. MARGETIĆ, Etnogeneza Hrvata i Slavena, Split, 2007; N. BUDAK, Nada Klaić i problem porijekla i dolaska Hrvata, in: T. GALOVIĆ - D. AGIČIĆ (eds.), Nada Klaić i njezin znanstveni i nastavni doprinos razvoju hrvatske historiografije, Zagreb, 2014, pp. 113-132.

${ }^{10} \mathrm{~N}$. BUDAK, Identities in Early Medieval Dalmatia $\left(7^{\text {th }}-11^{\text {th }} \mathrm{c}\right.$.), in: I. GARIPZANOV, P. GEARY and P. URBANCZYK (eds.), Franks, Northmen and Slavs: Identities and State Formation in Early Medieval Europe, Turnhout, 2008, pp. 223241; D. DZINO, Becoming Slav, becoming Croat. Identity Transformations in post-Roman and Early Medieval Dalmatia, Leiden - Boston, 2010.
} 
While V. A. Fine expressed an extreme opinion, denying the very existence of the Croatian ethnic identity before the nineteenth century, Dzino and myself tried to explain the mechanisms which resulted in the creation of this identity, be it ethnic or/and social. ${ }^{11}$

But even if there is no doubt in the existence of the Croatian identity, it is clear that not all the inhabitants of the former Roman province of Dalmatia - and not even all those living in its central part between the rivers Zrmanja and Cetina - used the Croatian name for their selfidentification, nor were they predominantly labeled by outsiders as Croats.

In order to understand better who used the Croatian name to identify himself and who was seen by others as belonging to the Croats, we should take a look at the cartulary of St. Peter, a source offering a perspective which can not be achieved through more official documents such as royal charters or chronicles. Though a Benedictine cartulary can also not be seen as an expression of an exclusively private opinion of its composer, it is true that Peter de Gumay entered the order at a late stage of his life and, moreover, the monastery was his own foundation which he treated, as we can trace through the notes in the cartulary, more or less as his private property. Therefore I believe that it is close to truth to claim that the document in its first part expresses Peter's own, personal view of ethnic and other identities in Split and the surroundings of the monastery.

On first sight it becomes obvious that ethnic names were only rarely used by the scribes of the cartulary. A rough estimation tells us that there are between 400 and 500 individuals mentioned in the text, many of them several times, while any kind of ethnic, regional or similar identification is used not more than forty times.

But the picture becomes even more interesting if we take a look at only the first part of the cartulary, the one which was composed before 1105 or just around that year. Since the texts were reflecting mostly different legal matters taking place in the surroundings of the monastery, on the territory which has for almost three centuries been under the rule of the Croatian kings, or maybe on the territory of Split (which at that time also was under Croatian suzerainity, but previously belonged to the Byzantine empire), one would expect a more often use of the designations 'Croats', 'Dalmatians', 'Slavs' or 'Latins'. These were the most common names given by authors of different sources to the population of the former province of Dalmatia or the later Kingdom of Croatia and Dalmatia. However, in the first part of St Peter's cartulary we can find three times the mention of Croats and never any of the other three identities. The Croatian name is used once as part of the title of king Zvonimir (rex Chroatorum Suinimir) and twice as a label of group identity: plurimi Spalatinorum Chroatorumque uirorom and de nobilibus Chroatensis et ignobilibus. ${ }^{12}$

Apart from the Croats, there is only one other ethnic name used by the scribes of the oldest part of the cartulary, and that is Langobardi. ${ }^{13}$ These Lombards were obviously merchants, maybe slave traders, from whom Peter bought a slave for the monastery.

All other groups, as well as a number of individuals, are described using territorial, rather than ethnic names. In the very first note, describing the erection and consecration of the church of St Peter (in 1080), Peter de Gumay oposes men from Split to the Croats: ${ }^{14}$

"... ad cuius solempnitatem quam plurimi Spalatinorum Chroatorumque uirorum gratia remissionis seu absolutionis uenerunt."

\footnotetext{
${ }^{11}$ V. A. FINE Jr., When Ethnicity did not Matter in the Balkans. A Study of Identity in Pre-Nationalist Croatia, Dalmatia, and Slavonia in the Medieval and Early-Modern Periods, Ann Arbor, 2006.; see my criticism of this book in Radovi Zavoda za hrvatsku povijest 41, 2009, pp. 487- 495 and in Speculum 86, March 2011, pp. 187-188. Also: N. BUDAK, Hrvatska i Bizant u 10. stoljeću, in: Tabula 12, 2014, pp. 51-63.

${ }^{12}$ Supetarski kartular, p. 213, No 1 and p. 227, No 96.

${ }^{13}$ Supetarski kartular, p. 226, No 89.

${ }^{14}$ Supetarski kartular, p. 213, No 1.
} 
Inhabitants of Split are mentioned on one more occasion. The nobles of Split (... multis Spalatinorum nobilibus...) were invited by Peter to decide upon a dispute he had with a certain Miroslav about some lands. ${ }^{15}$ One of the witnesses was Forminus Spalatinus. It is worth noting that neither Peter, no any other author of the notes felt the need to distinguish the inhabitants of Split from other people mentioned, except on these two occasions.

The most frequent designation is 'de Tugari', meaning people from the village (district) of Tugari, in the vicinity of the monastery, which is not surprising. It is either an individual (Girgi, Kerna, Andrea) described as 'de Tugari', or 'omnes Tugarani'. ${ }^{16}$ In a similar way there are also other people living in nearby villages or districts: Srinjine (Srenine), ${ }^{17} \breve{Z}$ rnovnica (Sirnounyza), ${ }^{18}$ Poljica (Campesani), ${ }^{19}$ Neretva (de Narento) ${ }^{20}$.

A somewhat broader 'circle of identification' comprises of inhabitants of different Dalmatian towns: Dubrovnik (Raguseus, Ragusei) ${ }^{21}$, Kotor (Catarini) ${ }^{22}$, Omiš (Olmisani) ${ }^{23}$ and Šibenik (Subbenzani $)^{24}$.

The note from 1176 is an example of a document added to the cartulary several decades after the primary part of the manuscript. ${ }^{25}$ It is a copy of a notarial document and therefore longer and more elaborate than most of the notes in the older part of the cartulary. It regards a dispute between the monastery and certain 'Slavs' and 'Latins' who claimed some lands in a place called Stupica (Stilpiza):

"Factum est quod in prenominato tempore quidam Sclaui Adrianiki, uidelicet Prodanus scilicet cum parentibus suis Sclauis et quidam Latini, uidelicet Jacobus de Aprizi, qui fuit eorum aduocatus, Dabrali Cascarus, Prodanne de Cicla, Psaulus et Nicolaus Caloianni et omnes eorum parentes, insurgentes aduersus monasterium sancti Petri de Gomai, ceperunt petere terras que sunt in loco qui dicitur Stilpiza asserentes utique qoud prenominate terre eisdem pro suo parentatu pertinerent et hereditario iure ipsas possidere uolebant. Tandem uero ad placitum deuenimus et (...) placitum habuimus hoc modo: conquerebantur itaque predicti Adrianiki de prefato monasterio quod memoratas terras sibi per uiolentiam et usurpationem retineret, quibus denique iuppanus Talmazo, noster aduocatus, de uoluntate et mandato omnium nostrum ita respondit: Monasterium sancti Petri de Gomai a longis retro temporibus sepedictas terras possedit, quas quidem terras Rossene Morsticus prius donauit monasterio sancti Petri de Gomai et post mortem ipsius Rossene Morstici, Petrus Slauus, filius eius, et Slauizo auunculus eiusdem Petri Slaui prenominatas terras in sepedicto monasterio confirmauit et eas in pace et magna quiete hactenus possedit, et quod a predictis iuris donatione et confirmatione prelibate terre nostro monasterio fuerint tradite."

It seems from the text (though there can be several interpretations of this fragment) that there was a group of people known as 'Adrianiki' and more precisely defined as Slavs, but also Latins, because in the second part of the document John, the monastery's procurator, mentions only 'predicti Adrianiki' which in my opinion should have included both Slavs and Latins. Skok presumed

\footnotetext{
${ }^{15}$ Supetarski kartular, p. 214, No 5.

${ }^{16}$ Supetarski kartular, p. 214, No 1; 214, No 3; p. 214, No 4; p. 215, No 6; p. 216, No 11; p. 221, No 52; p. 225, No 88.

${ }^{17}$ Supetarski kartular, p. 221, No 60; p. 228, No 96.

${ }^{18}$ Supetarski kartular, p. 221, No 55.

${ }^{19}$ Supetarski kartular, p. 221, No 55.

${ }^{20}$ Supetarski kartular, p. 221, No 53.

${ }^{21}$ Supetarski kartular, p. 217, No 17.

22 Supetarski kartular, p. 220, No 46.

${ }^{23}$ Supetarski kartular, p. 220, No 49.

${ }^{24}$ Supetarski kartular, p. 221, No 60.

25 Supetarski kartular, p. 228, No 97.
} 
that their name was related to the river Jadro, flowing in the vicinity of Split and the possessions of the abbey. ${ }^{26}$ There is no reason to reject his proposal, but this would mean that by the end of the $12^{\text {th }}$ century there were still 'Latins' living in the territories which have for almost four centuries been under Slavic rule. Since they both - the Slavs and the Latins - claimed that the disputed land belonged to them due to their kinship and hereditary rights, it follows that both groups belonged to the same lineage. What, then, became the reason for their differentiation into two groups which today we would primarily understand as ethnically different? We have to leave this question, for the moment, unaswered.

The lapidary genealogy of the family of Rusin Morsticus leads to other questions. Rusin Morsticus was, according to some authors, a Croatian dignitary who governed a part of the kingdom which included the coastal area near Split and the central Dalmatian islands. ${ }^{27} \mathrm{He}$ is also mentioned in the older part of the cartulary, as donator of lands to the monastery. ${ }^{28}$ After his death, his wife confirmed the donation, and so did his brother, Slauiz rex. In the 1176 charter Rusin's donation was confirmed by his son, Petrus Slauus and by Peter's uncle Slauizo. Slauiz and Slauizo are diminutivs of Slavus, which means that the designation 'Slav' was used for the members of this lineage through two generations and at least two members of the same generation simultaneously. Why was exactly this family highlighted as being Slavic, in a surrounding in which the majority had Slavic names and obviously spoke Slavonic (what is reflected not only in family names, but also place names and some linguistic changes in the contemporary vulgar Latin, as shown by Skok), remains unclear.

Of course, this single note does not allow us to draw conclusions about the practice of ethnic labeling just before the year 1200, but keeping in mind that only a few decades later the Split historian Thomas the Archdeacon will distinguish clearly between Latins (citizens of Dalmatian towns of Roman origin, but also those of Italian communes) and Croats (Slavs, whom he sometimes identifies with Goths), we might think that it was not by chance that the distinction between Slavs and Latins appears in this charter written by the Split notary Gualterius. ${ }^{29}$

The last part of the cartulary, containing notes from the $14^{\text {th }}$ century, differs from the previous two parts in mentioning more often the Croatian name: regnum Croatorum, de sex generibus Croatorum, duodecim tribus Croatorum; ${ }^{30}$ rex Croatorum Suinimir; ${ }^{31}$ de genere Croatorum, rex Croatorum; ${ }^{32}$ rex Croatorum Suenimir ${ }^{33}$. As was mentioned in the introduction to this article, this last part had been written in Split, most probably in the chapter. The $14^{\text {th }} \mathrm{c}$. was the time of great changes in political and social relations in Croatia. After a long period of Hungarian-Croatian kings who showed little interest in the coastal part of their kingdom, Louis the Great, the Angevin, managed to take over the central part of Croatia and put it under his direct control. The weakening of the magnates enabled the organizing and strengthening of the lesser nobility which gathered into the so called 'Brotherhood of the twelve Croatian tribes'. ${ }^{4}$ This resulted in spreading of the Croatian name among the less wealthy and influential inhabitants not only of the Croatian interior, but also in the Dalmatian towns which attracted many of the members of these noble kindreds. On the other hand, the pressure of

\footnotetext{
${ }^{26}$ Supetarski kartular, p. 280.

${ }^{27}$ GUNJAČA, Ispravci i dopune, pp. 73-129.

${ }^{28}$ Supetarski kartular, p. 223, No 72 and 73.

${ }^{29}$ Archdeacon Thomas of Split, History of the Bishops of Salona and Split, Latin text by O. PERIĆ, edited, translated and annotated by D. KARBIĆ, M. MATIJEVIĆ SOKOL and J. ROSS SWEENEY, Budapest - New York, 2006.

${ }^{30}$ Supetarski kartular, p. 230, No 100.

${ }^{31}$ Supetarski kartular, p. 230, No 101.

32 Supetarski kartular, p. 231, No 102.

${ }_{33}^{33}$ Supetarski kartular, p. 231, No 105.

${ }^{34}$ N. KLAIĆ, Postanak 'plemstva dvanaestoro plemena Kraljevine Hrvatske', in: Historijski zbornit 11-12 (1958-1959), pp. 121-163; T. RAUKAR, Seljak i plemić hrvatskoga srednjovjekovlja, Zagreb, 2002.
} 
the king provoked a reaction among the higher nobility, resulting, most probably, in the creation of the myth of king Zvonimir, 'the last king of the Croatian nation'. ${ }^{35}$ Different versions of this myth can be found in several chronicals and histories from the $14^{\text {th }}$ to the $16^{\text {th }} \mathrm{c}$. This growth of expressions of national identity among all strata of nobility found its way onto the pages of the cartulary of St Peter, long after the manuscript has lost its original function. That is why the Croatian name was written down several times in the note on the alleged way of electing Croatian kings or in the list of Croatian bans (vice kings) in time of the Croatian kings, who all came - according to the anonymous author - from some of the twelve noble kindreds.

Although ethnic names are rare in the cartulary of St Peter de Gumay, even so (or because of that) they might allow us to conclude how ethnic labeling was not a usual practice in Croatia and Dalmatia in the second half of the $11^{\text {th }} \mathrm{c}$. (and maybe also before that time). Split was incorporated into the Croatian kingdom and differences noted by the authors of the notes composed before 1105 were predominantly local ones: somebody belonged to a local community, like the Tugarani, or was an inhabitant of a town (Split, Dubrovnik...). Only 'real' foreigners, the Lombards, were labeled with their ethnic name (unless the abbot writing about the purchase of a slave from these merchants used the name as a mark of regional belonging). With the growing separation of the communes from their hinterland, during the late $12^{\text {th }} \mathrm{c}$., ethnic differentiation became more expressed. It is also not clear whom did the composers of the cartulary recognize as Croats. They were obviously not all the people living outside the Split territory, but also not some kind of social elite, because there were both noble and ignoble Croats. But again, it was tending more to describe the territorial separation, than an ethnic one in the way we would understand it today, because the Dalmatian towns were almost as Slavic as their hinterland. Finally, in the Late Middle Ages the expression of ethnic/national identity became more common and the pages of the cartulary were used to provide support for this new tendency. ${ }^{36}$ Further research might support, but also deny this thesis.

\section{ETNIČKO OZNAČAVANJE U KARTULARU SAMOSTANA SV. PETRA DE GUMAY KRAJ SPLITA}

Analiza kartulara samostana sv. Petra u Selu koju je prilikom izdavanja tog važnog izvora proveo Viktor Novak pokazala je da je tekst kartulara nastao u tri dijela. Prvi dio, koji je i najopsežniji, sastoji se od bilježaka nastalih prije 1105., koje su prepisala dvojica pisara. Drugi je dio nastao u 12. st., a svakako prije tatarske provale, nakon koje se samostan više ne spominje (iako arheološki tragovi upućuju na to da je barem crkva bila u upotrebi i kasnije). Treći se dio sastoji od upisa nastalih u 14. st. Kartular se u to vrijeme, po svoj prilici, nalazio u Splitskom kaptolu.

Ovaj se rad bavi analizom etničkih oznaka koje se spominju u kartularu. Iako izvor u tom pogledu ne nudi puno podataka, ipak je zanimljiv, jer za razliku od isprava, koje imaju službeni karakter, bilješke u kartularu dobrim dijelom odražavaju osobnu praksu Petra Crnog i njegove subraće u samostanu u identificiranju pojedinaca prema njihovoj etničkoj ili lokalnoj pripadnosti. Time nam otkrivaju barem djelomično svakodnevnu upotrebu etničkih i drugih oznaka, što nam može pomoći u boljem razumijevanju etnogenetskih (ili identifikacijskih) procesa u Hrvatskoj i Dalmaciji.

U kartularu se koristi se vrlo mali broj etničkih oznaka. Iako je u kartularu spomenuto 400-500 pojedinaca, bilo kakve oznake pripadnosti koriste se tek četrdesetak puta. Hrvati su u prvom (i dru-

\footnotetext{
${ }^{35}$ I. GOLDSTEIN, Kako, kada i zašto je nastala legenda o nasilnoj smrti kralja Zvonimira?, in: Radovi Instituta za hrvatsku povijest 17 (1984), pp. 35-54.

${ }^{36}$ On national identity in the Late Middle Ages: A. D. SMITH, National Identities: Modern and Medieval?, in: S. FORDE, L. JOHNSON and A. V. MURRAY (eds.), Concepts of National Identities in the Middle Ages, Leeds, 1995, pp. 21-46.
} 
gom) dijelu kartulara spomenuti samo tri puta: jednom u Zvonimirovoj tituli (rex Chroatorum Suinimir) i dva puta kao oznaka grupnog identiteta: plurimi Spalatinorum Chroatorumque uirorom i de nobilibus Chroatensis et ignobilibus. Osim njih, spominju se samo Langobardi od kojih je Petar Crni kupio jednog roba, te Splićani u već navedenom citatu i još jednom kao splitski plemići (...multis Spalatinorum nobilibus...). Oznaka 'Splićani' mogla bi se okarakterizirati kao lokalna, ali s obzirom na to da je suprotstavljena Hrvatima ne može biti izjednačena s oznakom pripadnosti nekom selu u okolici samostana. Slično se može gledati na stanovnike drugih gradova, spomenute u tekstu (Dubrovčani, Šibenčani, Omišani, Kotorani). Nejasno je tko su za sastavljače kartulara bili Hrvati. Taj se naziv očito ne odnosi na sve stanovnike izvan splitskog teritorija, ali niti na neku društvenu elitu, jer se spominju plemeniti i neplemeniti Hrvati.

Među oznakama lokalnog karaktera, najčešća je 'Tugarani'. Ona se koristi ili za pobliže određivanje pojedinaca (Girgi, Kerna, Andrea), ili kao 'omnes Tugarani'. ${ }^{37}$ Slično je s ljudima iz drugih mjesta u bližoj ili daljoj okolici samostana: Srinjina, Žrnovnice, iz Poljica ili s Neretve.

Notarska isprava iz 1176., prepisana u kartular, govori o sukobu oko zemlje u koji su bili umiješani neki Slaveni i Latini. Jedna skupina pobliže je opisana kao 'Adrianiki', za što je Skok, vjerojatno s pravom, pretpostavio da se odnosi na one koji su živjeli uz rijeku Jadro. Dokument u tom smislu nije lako protumačiti, jer se može razumjeti da su ti Adrijanići bili i Slaveni i Latini. osim toga, to bi značilo i da su među Slavenima u splitskom zaleđu u 11. st. još uvijek živjeli i neki koji su bili opisivani kao Latini.

S ovom je ispravom u vezi i pitanje genealogije Rusina morstika. On je vjerojatno bio župan Kliške županije, a bio je i brat kralja Slavca (Slauiz rex). U ispravi, Rusinovu donaciju samostanu potvrđuje njegov sin Petrus Slauus i Petrov ujak Slauizo. Slauiz i Slauizo su deminutivi imena Slavus, što znači da se oznaka slavenske pripadnosti u ovom rodu koristila za neke njegove članove kroz barem dvije generacije i za najmanje dvojicu istovremeno. Nejasno je zašto bi pripadnici jednog roda koji je živio u slavenskom ili gotovo potpuno slaveniziranom okružju (kakav je tada bio i Split) bili označeni kao Slaveni? Imajući ipak u vidu da će samo nekoliko desetljeća kasnije Toma Arhiđakon praviti jasnu razliku između Latina (Romana) u Splitu i Hrvata (Slavena, Gota) u zaleđu, možda ova pojava razlikovanja Latina i Slavena 1179. nije slučajna, već je naznaka postupnog odvajanja Splita od svojeg zaleđa. Naravno, pritom se nije radilo toliko o etničkom razlikovanju, koliko o kulturološkom i opoziciji grad : selo.

U trećem se dijelu kartulara, nastalom u 14. st., više puta spominju Hrvati: regnum Croatorum, de sex generibus Croatorum, duodecim tribus Croatorum; rex Croatorum Suinimir; de genere Croatorum, rex Croatorum; rex Croatorum Suenimir. Može se pretpostaviti da je to rezultat promijenjenih političkih odnosa u Hrvatskoj, u vrijeme kada je Ludovik Anžuvinac oslabio moć magnata i omogućio nižem plemstvu određenu emancipaciju i stvaranje Bratstva dvanaestoro hrvatskih plemena. S druge strane, oslabljeni magnati mogli su poticati nostalgiju za vremenom samostalnoga kraljevstva čiji su kraj identificirali sa Zvonimirovom smrću. Jačanje osjećaja pripadnosti hrvatstvu našlo je tako svoj iskaz na stranicama kartulara, u vrijeme kada je izgubio svoju prvotnu funkciju i postao podloga za sastavljanje bilješki koje sa samostanom više nisu imale veze.

Iz navedenog se može zaključiti da je u 11. st. praksa upotrebe etničkih oznaka na splitskom području bila rijetka, možda zato jer je Split bio u to vrijeme dobro integriran sa svojim zaleđem. Postupno odvajanje, koje je bilo posljedica oblikovanja komunalnog društva i stvaranja osjećaja posebnosti, dovelo je do toga da se jasnije počinje razlikovati dvije skupine stanovnika: Latine i Slavene, mada nam ono što je bilo temelj te podjele ipak ostaje nedovoljno vidljivo. Napokon, u 14. st. se kod plemstva javlja određeni osjećaj pripadnosti hrvatskom etnosu, koji će stvoriti mitove koji su ostali zabilježeni u Supetarskom kartularu.

Ključne riječi: etnički identitet, nacionalni identitet, Hrvatska, Dalmacija, razvijeni srednji vijek

${ }^{37}$ Supetarski kartular, p. 214, no1; 214, No 3; p. 214, No 4; p. 215, No 6; p. 216, No 11; p. 221, No 52; p. 225, No 88. 